\title{
Perspectives
}

\section{Reconsidering the Effectiveness and Suitability of PPP and TBLT in the Japanese EFL Classroom}

\section{Rintaro Sato (佐藤臨太郎) \\ Nara University of Education}

With the recent high-profile utilization of tasks in language classrooms, the longestablished traditional teaching methodology based on the presentation-practiceproduction (PPP) model is now being replaced by task-based language teaching (TBLT) in SLA (e.g., Skehan, 1996, 1998; White, 1988; Willis, 1996, 2004). However, in the Japanese EFL learning environment, there is still considerable skepticism regarding the effectiveness of TBLT. This paper explores the suitability of TBLT and PPP in the Japanese secondary school context and discusses the relative effectiveness of PPP from the point of view of skill acquisition theory. Some suggestions for effective teaching procedures are also discussed.

実践的コミュニケーション能力育成の重要性が高まるなか、TBLT （task-based language teaching）の効果が最近日本の英語教育現場において注目されている。一方、伝統的な PPP (Presentation-Practice-Production) モデルが、第2言語習得研究において否定されつつあ るが、日本の外国語としての英語学習状況においてはTBLTに対して懐疑的な見方があるのも 事実である。本稿では、PPPの効果について、日本の英語学習環境やskill acquisition theoryの 観点から分析し、TBLT の効果について、その日本の教室現場での活用における問題点を指摘 する。さらにPPPとTBLTを比較検討することにより、日本の英語教育においてのより効果的な アプローチについて提案する。

JALT Journal, Vol. 32, No. 2, November 2010 
The Ministry of Education, Culture, Sports, Science, and Technology (MEXT) has declared that one of the overall objectives of English education in junior high school is to develop basic communication abilities (MEXT, 2008), and furthermore to develop communication abilities to convey information and express ideas and opinions in senior high school (MEXT, 2009). MEXT (2008) clearly states that "students should be engaged in activities that will lead them to exchange their thoughts and feelings by actually using the English language" (p. 6). The utilization of task-based language teaching (TBLT), which is a logical development of communicative language teaching (Willis, 1996), has been recently gaining attention for English teaching in Japan (e.g., Matsumura, 2009; Takashima, 2000, 2005).

Ellis (2003) defines a task as follows:

1. A task is a work plan.

2. A task involves a primary focus on meaning.

3. A task involves real-world processes of language use.

4. A task can involve any of the four language skills.

5. A task engages the cognitive process.

6. A task has a clearly defined communicative outcome. (pp. 9-10)

In the presentation-practice-production (PPP) model, practice of specified target structures in production has a crucial role. The teacher starts by explaining some specific new forms and meanings of the L2. Skehan (1998) summarizes PPP as follows: "The first stage is generally focused on a single point of grammar which is presented explicitly or implicitly to maximize the chances that the underlying rule will be understood and internalized. This would essentially aim at the development of declarative knowledge" (p. 9). Then, learners move on to a practice stage, focusing mainly on accuracy, subject to the teacher's careful supervision or control. In the practice stage, which is aimed at converting declarative knowledge to procedural knowledge, control is gradually loosened as learners move to the next stage, production, at which point they are provided with opportunities to produce the target form, sometimes through communicative activities. In this production stage, Skehan notes that "learners would be required to produce language more spontaneously, based on meanings the learner himself or herself would want to express" (p. 93).

Proponents of TBLT dismiss the traditional PPP approach (e.g., Skehan, 1996, 1998; White, 1988; Willis, 1996, 2004). Skehan (1996) claims that "the belief that a precise focus on a particular form leads to learning and au- 
tomatization no longer carries much credibility in linguistics or psychology" (p. 18). Willis (1996) also asserts that "language learning rarely happens in an additive fashion" (p. 135). Skehan (1998) states that "such an approach [i.e., PPP] is now out of fashion" (p. 94) and White (1988) discredits the PPP approach as a meaning-impoverished methodology.

However, the effectiveness of TBLT, especially in teaching grammar, can be questioned: TBLT may not be effective in teaching pre-specified target structures; it is not designed for examinations; and the Japanese language is the primary medium in a Japanese classroom. Dismissing PPP completely from our classrooms may be premature since the effectiveness of this approach has not fully been tested by SLA researchers (DeKeyser, 1998). Taking account of the Japanese EFL situation in which students do not have much exposure to English and have little need for communication in English in their daily lives, it is crucial to reconsider the effects of the traditional PPP approach and compare them with those of TBLT.

\section{Reconsidering the Suitability of TBLT in the Japanese EFL Classroom Target Grammatical Structures}

In teaching English in Japanese secondary schools, teachers have to use textbooks authorized by the Japanese government. These textbooks require students to learn a target grammatical structure in each section. It may be true that language learning does not occur in a linear, additive way (Willis, 2004), but pedagogical activities in the textbooks are systematically arranged in a way that requires students to learn the target language in a stepby-step way. In a typical task activity, in which students focus on meaning or communication to complete the task, the target grammatical structure cannot always be used by the students.

To examine whether students actually use a target structure or not and how they feel about a given task, I conducted a very simple experiment with 21 university students majoring in English education at a national university in Japan. In the task, extracted from Takashima (2005), students were put in a situation where they were implicitly encouraged to use the present perfect. The following was the procedure:

1. Students made pairs (one student was paired with me).

2. Each of the students was given a sheet which included different information from their partner's sheet. 
3. Referring to the sheets which had (1) information on what they had eaten before the Golden Week (GW) holidays, (2) a restaurant recommended by their mother, and (3) plans after GW, they were required to talk with their partner to decide which restaurant to go to during the holiday.

4. One student from each pair reported their final decision and the reasons why they chose a particular restaurant.

5. Students then completed a brief survey which asked whether they had used the target present perfect grammar during the task, and they were asked to write comments about the task.

This brief experiment showed that 15 students did not produce sentences with the target grammar at all. In my particular pairing with a student, I found that my partner had no immediate need to use the target grammar to complete the goal of the task. Some of the comments written by the students further highlighted some of the issues with the task (comments were originally written in Japanese and translated into English by the author):

- $\quad$ Student A: I really enjoyed doing the task. It was like playing a game.

- Student B: I used the past and future tense but I did not have to use the present perfect to complete the task.

- Student C: When I couldn't say in English what I really wanted to mean, I spoke in Japanese.

- $\quad$ Student D: I don't know if I learned something in the activity, but anyway it was fun.

As the task allows learners to choose the language needed to achieve the outcome of the task (Ellis, 2003) and learners are given the freedom to decide which grammatical items to use, the unlikelihood that learners will produce the target items in a task is quite understandable. It is crucial for Japanese learners, most of whom have exposure to English only in an English class, to learn new items during the class. However, the task may not meet this need. Ellis (2003) admitted that students often regard communicative tasks as opportunities for communication rather than learning. As an advantage of TBLT, Willis (1996) stated that "the role of tasks is to encourage learners to activate and use whatever language they already have, both for comprehension and for speaking and writing" (p. 147), and "it provides learners with the motivation to improve and build on whatever 
language they already have" (p. 1). This statement is consistent with Swain's claim (2005) that TBLT is suitable for advanced learners. University students engaged in the experiment above can be regarded as relatively higher level students as they had obtained high scores in the entrance exams for the national university and were majoring in English, but the fact that the task was not effective even for those higher level learners-in that most of them did not have to use the target grammatical structure-implies that it might be even less effective for junior and senior high school students. If new language items cannot be learned purposefully through a task, and if we refer to Bruton's (2005) conclusion that a task has limited applicability for EFL students, we can be skeptical of the appropriateness of task-based approaches for Japanese students. Takashima (2005) contended that many Japanese EFL learners might not be able to adequately use target vocabulary and grammatical structures in the task context of TBLT, and he introduced focused-task activities that he believed are more applicable in the Japanese secondary school learning environment.

\section{Examinations and Tests}

Yashima (2000) pointed out that Japanese learners have dual goals, namely, a practical realistic goal related to tests, and a goal related to using English for communication; and these learners may attach a greater or lesser degree of importance to each of these goals. It seems that most Japanese students have test-related motivation rather than communicationrelated motivation (Yashima, Zenuck-Nishide, \& Shimizu, 2004). It cannot be denied that most Japanese secondary students study English for tests that mostly measure accurate knowledge of English rather than communicative language ability. Willis and Willis (2007) stated that task-based teaching is not designed with examinations in mind, and that it is designed to produce learners who can use their English outside the classroom, even if they make grammatical mistakes or errors. Needless to say, examinations have been a key factor in Japanese secondary school students' English learning and have had significant influence. Japanese students are still being given traditional high-stakes tests such as end-term tests or tests for entrance examinations, which include reading and sometimes writing and even listening, but not speaking. There is therefore a mismatch between examinations and taskbased language teaching. 


\section{English Classes Conducted in Japanese}

In the TBLT classroom, "generally it is best to do all the classroom organization and instruction giving in English, as this creates a very real context and purpose for listening" (Willis \& Willis, 2007, p. 220). The concern in Japanese secondary schools is that English is not the primary medium in the Japanese English classroom. According to the results of a survey conducted by MEXT, less than one-third of teachers in junior high school and less than $10 \%$ of senior high teachers conduct their classes mainly in English (Kan, 2006). This long-standing issue of the English class dominated by the Japanese language should certainly be addressed. However, as long as Japanese teachers of English use Japanese for communication, students will follow their teachers and overuse their shared mother tongue in pair or group work. A precondition for TBLT is the establishing of the English-forcommunication class. Facing the fact that Japanese is the primary language in the English classroom, the introduction of TBLT may be premature, notwithstanding the stated MEXT objectives.

\section{Reconsidering the Utilization of PPP}

\section{Declarative Knowledge and Procedural Knowledge}

In the process of second language learning, learners learn or acquire two different types of knowledge, namely, declarative knowledge and procedural knowledge. Declarative knowledge is factual knowledge that is expressed explicitly, for example, knowing that the capital of Japan is Tokyo and its former name was Edo, or knowing that English has two articles: the definite article the and the indefinite article $a$ or $a n$. In contrast to this type of knowledge, procedural knowledge can only be performed. Knowing how to use the English articles the and $a$, or knowing how to swim or ride a bicycle are examples of procedural knowledge. In the input-scarce environment of Japan, students first acquire declarative knowledge in a formal class and then this knowledge develops into procedural knowledge through practice or exposure (Sharwood Smith, 1981). Anderson (1992) tells us that procedural knowledge is declarative knowledge that has been fully automatized, leading us to conclude that acquisition of procedural knowledge should be a final goal of second language learning.

\section{Skill Acquisition Theory}

In his skill acquisition theory, Anderson $(1993,1995)$ claimed that second language learning starts out in declarative form, progresses to the stage of 
proceduralization through extensive practice, and then knowledge becomes automatic. Anderson (1995) divided the process of skill acquisition into three stages, namely, a cognitive, an associative, and an autonomous stage. He noted that declarative knowledge corresponds to the cognitive stage, proceduralization of knowledge corresponds to the associative stage, and automatizing procedural knowledge is on a parallel with the autonomous stage. In the cognitive stage, students learn a set of facts relevant to the skill (declarative knowledge). In the associative stage, they strengthen the connections among the elements needed for successful performance, detecting and eliminating errors, and converting declarative knowledge into a procedural form. In the autonomous stage, students continue developing procedural knowledge, and perform the skill better and more automatically. Anderson (1993) conceded that not all knowledge starts with the declarative form, developing into the procedural, and that acquisition of procedural knowledge does not always mean the loss of declarative knowledge. However, the important point in the theory is that learners initially learn declarative knowledge and then develop it into procedural knowledge through engaging in the target behavior.

\section{PPP and Skill Acquisition Theory}

The effectiveness of the PPP approach can be examined from the point of view of skill acquisition theory. According to DeKeyser (1998), the theory implies that learners should be given explicit teaching of the target grammar first (cognitive stage), followed by activities or practice to develop their acquired or learned declarative knowledge into procedural knowledge (associative stage), and then less focused communicative activities to enhance proceduralization and automatization (autonomous stage). In a typical PPP lesson, a target language item is introduced by the teacher to clarify its meaning in the presentation stage, which corresponds to the cognitive stage in skill acquisition theory. In the practice stage, students repeat and practice target items or sentences with activities such as pattern practice, drills, and answering questions using a specified form. This stage, whose activities seem to be completely dismissed in TBLT, can be regarded as the associative stage in skill acquisition theory. The production stage, in which students are expected to produce language items they have just learned with other previously learned languages, can be compared to the autonomous stage. Byrne (1986) stated that the practice stage in PPP roughly corresponds to Anderson's procedurization stage, and the production stage corresponds to automatization. Supporting Anderson's theory (1993), Yamaoka (2005, 
2006) argued that imitation, repetition, and pattern practice are essential for the development of declarative knowledge into procedural knowledge in the Japanese EFL environment. DeKeyser (2001) concluded that it is desirable that activities be introduced after a rule-based model in which language is learned through a formula, because with explicit teaching students can notice the new structure and process its form-meaning link so that they can finally acquire it. It can safely be said that the PPP approach is compatible with skill acquisition theory in that the approach can enhance the transition of students' knowledge from declarative to procedural.

\section{Suggestion}

It is definitely important for Japanese students, who rarely have opportunities to use English for communication outside the classroom, to learn, acquire, and use target structures within the class period. Anderson's skill acquisition theory $(1993,1995)$ claimed that practice or focused tasks have a role to play in learning, contributing to the development of declarative knowledge into procedural knowledge. With that as a reference, it seems that the traditional PPP type approach is still practical and beneficial for learning in Japanese secondary schools. Students are required to learn target structures effectively and efficiently within a limited amount of time.

However, there are some considerations to bear in mind when creating and conducting English classes based on the PPP approach. Yamaoka (2005) warned that learners should experience meaning-form connections during practice in order to develop procedural knowledge. He dismissed the simplistic, mechanical imitation and repetition often seen in the traditional PPP approach and advocated complex, active imitation and repetition, connecting form with meaning in language learning. He also stated that instead of simple, mechanical oral pattern practice, cognitive practice is required to establish form-meaning connections. Similarly DeKeyser (1998) claimed that mechanical drills or rushed output are far from ideal for the development of declarative and procedural knowledge. In skill-based language teaching, activities or practice are carried out after declarative explanation of target items, which is consistent with the PPP approach. In the practice stage, bearing in mind the disadvantages of disconnecting form and meaning (namely that it results in parrot-like repetitive practice or mechanical drills [see DeKeyser, 1998; Yamaoka, 2005, 2006]), a large amount of practice in context is required so that declarative knowledge can develop into procedural knowledge. A study by Gatbonton and Segalowitz (1988) concluded that communicative activities should be devised to allow learners to use the same expressions and formulas 
repeatedly. Arevart and Nation (1991) introduced an activity in which learners tell the same story several times, with increasingly strict time limitations, and they noted the positive effect on acquisition of having the learners use the same vocabulary items and formulas many times in a row. It is desirable to provide practice which allows learners to use the target rules or expressions repeatedly in a context where a connection between form and meaning can be established (DeKeyser, 2001).

In the last production stage, more open activities and tasks focusing primarily on meaning that are not designed for the use of a specific form, such as opinion gap tasks, can be used. However, we could argue that focused activities, which intrinsically require learners to use the target items repeatedly, can still be effectively employed. Presumably, activities which give priority to producing the target structure accurately can be criticized from the TBLT point of view. Willis (1996), for example, argues that students sometimes overuse the target structures and that they are still "in practice mode" (p. 134) trying to show control of the structure rather than expressing their own meanings. However, considering that learners should be encouraged to learn the new grammatical structures rather than simply using structures they have already learned and internalized, the use of focused practice in the production stage is rational.

In the Japanese EFL context, where there is little or no practical need to use English outside the classroom, not a few students study English as a school subject rather than as a practical language, and their aim is just to obtain high scores in high-stakes tests. In competitive examination systems, accuracy-focused written tests are seen as a key factor affecting teaching and learning. There seems to be a mismatch between this situation and the kind of speaking-oriented communicative activities carried out in TBLT. It is therefore vital for reading, writing, and listening activities to be implemented even at the production stage. An example of a technique that can meet this requirement is the dictogloss devised by Wajnryb (1990). In this procedure, students listen to a text two or three times and then reconstruct it. The text is designed to draw students' attention to a specific target grammatical feature. This kind of focused task involving listening and writing can integrate production and the requirements of written tests.

\section{Conclusion}

It is true that the task-based approach, which developed out of communicative language teaching, continues to attract keen attention. However, 
as this approach does not take sufficient account of the particular English learning environment in Japan, it may not be as practical in its application as the PPP approach. One serious problem of the PPP approach in the Japanese classroom in general is that the last $\mathrm{P}$ (production) stage is not given enough time in order for students to improve their communication (e.g., Izumi, 2009; Takashima, personal communication, December 13, 2009). Additionally, if teachers put too much emphasis only on mechanical activities in the second $\mathrm{P}$ (practice) stage without context, it is likely this will not lead to learning (Yamaoka, 2005, 2006). Lucas (1984) has pointed out that use of teaching methods relying heavily on tightly controlled drills and exercises has led to the poor English speaking ability of Japanese students. With these criticisms in mind, some revisions to the traditional PPP approach are obviously needed. However, with these revisions, it may still be the most suitable approach here in Japan.

The effect of TBLT, however, should not be dismissed since it can improve learners' motivation and help develop true fluency in an L2 (DeKeyser, 1998) by putting students in a situation where they can use English for real communication. By being provided with opportunities to actually use the language, students are motivated to talk in English (e.g., Nakahira, Yashima, \& Maekawa, 2010). Tasks also can activate the atmosphere of the English classroom, improving students' positive attitude for communication (Matsumura, 2009). With PPP used as the primary approach, tasks can be effectively used in the third stage, the production stage.

As Ellis (2006) mentions, there is not just one effective approach to teaching grammar: the acquisition or learning of grammar of a second or a foreign language is a complex process. We should recognize "what options are available, what the theoretical rationales for these options are, and what the problems are with these rationales" (p. 103). I hope this paper will provide a good opportunity for teachers to reconsider their own teaching in order to conduct more effective English classes in the Japanese secondary school context. Rather than considering the respective approaches as an unhealthy dichotomy, we need to make room for some kind of combination of methods, taking from each to better serve the contextual realities. However, given the particular language teaching realities in Japan, especially at the high school level, there is still a very strong case to be made for the effectiveness of the PPP approach.

Rintaro Sato is an Associate Professor in the Department of English Education of Nara University of Education. His research interests include intake and output processing, feedback, and negotiation of meaning. 


\section{References}

Anderson, J. (1993). Rules of the mind. Hillsdale, NJ: Lawrence Erlbaum.

Anderson, J. (1995). Developing expertise. In J. R. Anderson (Ed.), Cognitive psychology and its implications (4th ed.) (pp. 272-304). New York: W. H. Freeman and Company.

Arevart, S. \& Nation, P. (1991). Fluency improvement in a second language. RELC Journal, 22, 84-94.

Bruton, A. (2005). Task-based language teaching for the state of secondary FL classroom. Language Learning Journal, 31, 55-68.

Byrne, D. (1986). Teaching oral English (2nd ed.). Harlow, UK: Longman.

DeKeyser, R. (1998). Beyond focus on form: Cognitive perspectives on learning and practicing second language grammar. In C. Doughty \& J. Williams (Eds.), Focus on form in classroom second language acquisition (pp. 42-63). Cambridge: Cambridge University Press.

DeKeyser, R. (2001). Automaticity and automatization. In P. Robinson (Ed.), Cognition and second language instruction (pp. 125-151). New York: Cambridge University Press.

Ellis, R. (2003). Task-based language learning and teaching. Oxford: Oxford University Press.

Ellis, R. (2006). Current issues in the teaching of grammar: An SLA perspective. TESOL Quarterly, 40, 80-107.

Gatbonton, E. \& Segalowitz, N. (1988). Creative automatization: Principles for promoting fluency within a communicative framework. TESOL Quarterly, 22, 473-492.

Izumi, S. (2009). Focus on form wo toriireta atarashii eigo kyouiku [New English education which includes focus on form]. Tokyo: Taisyuukan Shoten.

Kan, M. (2006). Nihon no eigo kyouiku no genjo to kadai [The actual situation of English education in Japan and problems]. In Y. Otsu (Ed.), Nihon no eigo kyouiku ni hitsuyou na koto [Things required in English education in Japan] (pp. 171-182). Tokyo: Keiogijuku Daigaku Shuppankai.

Lucas, J. (1984). Communication apprehension in the ESL classroom: Getting our students to talk. Foreign Language Annals, 17, 593-598.

Matsumura, M. (2009). Eigo kyouiku wo shiru 58 no kagi [58 key factors for English education]. Tokyo: Taisyuukan Shoten.

MEXT. (2008). Course of study for junior high schools foreign languages (English). Tokyo: Tokyo Shoseki.

MEXT. (2009). Koutougakko gakushu shido yoryo [Course of study for senior high schools]. Kyoto: Higashiyama Shobo. 
Nakahira, S., Yashima, T., \& Maekawa, T. (2010). Relationships among motivation, psychological needs, FL WTC, and Can-Do statements of English language learning based on Self-Determination Theory: Preliminary study of non-English-major junior college students in Japan. JACET Kansai Journal, 12, 44-55.

Sharwood Smith, M. (1981). Consciousness-raising and the second language learner. Applied Linguistics, 2, 159-169.

Skehan, P. (1996). Second language acquisition research and task-based instruction. In J. Willis \& D. Willis (Eds.), Challenge and change in language teaching (pp.1730). Oxford: Heinemann.

Skehan, P. (1998). A cognitive approach to language learning. Oxford: Oxford University Press.

Swain, M. (2005). Legislation by hypothesis: The case of task-based instruction. $A p$ plied Linguistics, 26, 376-401.

Takashima, H. (2000). Jissenteki communication noryoku no tame no eigo tasuku katsudo to bunpou shidou [English task activities and grammar teaching for practical communication abilities]. Tokyo: Taisyuukan Shoten.

Takashima, H. (2005). Eigo no tasuku katsudo to tasuku. [English tasks activities and tasks]. Tokyo: Taisyuukan Shoten.

Wajnryb, R. (1990). Grammar dictation. Oxford: Oxford University Press.

White, R. (1988). The ELT curriculum. Oxford: Blackwell.

Willis, D., \& Willis, J. (2007). Doing task-based teaching. Oxford: Oxford University Press.

Willis, J. (1996). A framework for task-based learning. Harlow, UK: Longman.

Willis, J. (2004). Perspectives on task-based instruction: Understanding our practices, acknowledging our different practitioners. In B. L. Leaver \& J. Willis (Eds.), Task-based instruction in foreign language education (pp. 3-44). Washington, DC: Georgetown University Press.

Yamaoka, T. (2005). From item learning to category learning: A learning process of procedural knowledge of learning. ARELE, 16, 21-30.

Yamaoka, T. (2006). On the importance of imitation and repetition in foreign language learning. ARELE, 17, 1-10.

Yashima, T. (2000). Orientations and motivation in foreign language-learning: A study of Japanese college students. JACET Bulletin, 31, 121-133.

Yashima, T., Zenuk-Nishide, L., \& Shimizu, K. (2004). The influence of attitudes and affect on willingness to communicate and second language communication. Language Learning, 54, 119-152. 


\title{
Reviews
}

\section{The Handbook of Language Teaching. Michael H. Long and Catherine J. Doughty (Eds.). Oxford: Wiley-Blackwell, 2009. xix +801 pp.}

\author{
Reviewed by \\ Thomas Amundrud \\ Ritsumeikan University, Kyoto
}

Every year, volumes are published that presume to be the sort that researcher-practitioners will regularly consult for years to come. To this end, The Handbook of Language Teaching largely succeeds. Editors Michael Long and Catherine Doughty, whose previous Handbook of Second Language Acquisition (2003) is already a standard in the field, have managed to cover a wide range of issues pertinent to language teaching in a concise, practical, and generally accessible manner.

The Handbook of Language Teaching is, as befits its subject, quite broad in scope. Therefore, readers may benefit from considering possible maps for their journeys through the volume, using either those provided by the sections and chapters, or making their own way through the subject index.

For those looking for general introductions, the book is conveniently categorized into seven content areas (social, political, and educational contexts; the psycholinguistic underpinnings of language learning; program design; materials writing and course design; teaching and testing; teacher education; and assessment and evaluation). Many of the 39 chapters simply provide an overview of the topic; these would be a convenient first step on an investigatory journey and could also provide useful comparisons for more knowledgeable readers. For instance, in "Investigating the Effects and Effectiveness of L2 Instruction," De Graff and Housen look at research issues in SLA regarding the role of instruction in language learning, consider the

JALT Journal, Vol. 32, No. 2, November 2010 